Article

\title{
Survival of Lactobacillus paracasei subsp. paracasei LBC 81 in Fermented Beverage from Chickpeas and Coconut in a Static In Vitro Digestion Model
}

\author{
Maria Carolina Mesquita ${ }^{1, *}$, Eliana dos Santos Leandro ${ }^{1}$, Ernandes Rodrigues de Alencar ${ }^{2}$ (D) \\ and Raquel Braz Assunção Botelho ${ }^{1}$ D \\ 1 Department of Nutrition, College of Health Sciences, University of Brasília, Brasília 70910900, DF, Brazil; \\ elisanleandro@yahoo.com.br (E.d.S.L.); raquelbotelho@unb.br (R.B.A.B.) \\ 2 College of Agronomy and Veterinary Medicine, University of Brasília, Brasília 70910900, DF, Brazil; \\ ernandesalencar@gmail.com \\ * Correspondence: mariacarolinamesquitasantos@gmail.com
}

\section{check for}

updates

Citation: Mesquita, M.C.; dos Santos Leandro, E.; Rodrigues de Alencar, E.; Botelho, R.B.A. Survival of Lactobacillus paracasei subsp. paracasei LBC 81 in Fermented Beverage from Chickpeas and Coconut in a Static In Vitro Digestion Model. Fermentation 2021, 7, 135. https://doi.org/ 10.3390 / fermentation7030135

Academic Editors: Francesco Grieco and Vittorio Capozzi

Received: 7 July 2021

Accepted: 26 July 2021

Published: 28 July 2021

Publisher's Note: MDPI stays neutral with regard to jurisdictional claims in published maps and institutional affiliations.

Copyright: (c) 2021 by the authors. Licensee MDPI, Basel, Switzerland. This article is an open access article distributed under the terms and conditions of the Creative Commons Attribution (CC BY) license (https:/ / creativecommons.org/licenses/by/ $4.0 /)$.

\begin{abstract}
The objective of this study was to evaluate in a static in vitro digestion model the survival of Lactobacillus paracasei subsp. paracasei LBC 81 in fermented chickpea and coconut beverage. The fermented beverage was stored for 1 and 8 days at $4{ }^{\circ} \mathrm{C}$ and then submitted to gastric juice, pancreatic juice, or sequential exposure to gastric and pancreatic juice. The experiment controls were (i) control 1 -suspension of cells in $0.85 \%$ saline solution; (ii) control 2-cell suspension in chickpea and coconut beverage. The survival of L. paracasei was determined in $\log \mathrm{CFU} / \mathrm{mL}$ and expressed as a survival percentage. The survival of $L$. paracasei in the fermented beverage after exposure to gastric juice and sequential exposure to gastric and pancreatic juice was $99.47+2.05 \%$ and $93.21+0.43 \%$, respectively. These values were higher than those found for controls 1 and 2 . The storage condition of the fermented beverage for 1 or 8 days at $4{ }^{\circ} \mathrm{C}$ did not affect the survival after exposure to gastric juice, pancreatic juice, or sequential exposure. The results obtained in this study conclude that the fermented beverage of chickpeas and coconut is an excellent carrier for L. paracasei LBC 81, capable of enhancing survival to gastrointestinal conditions and ensuring a greater number of viable cells reaching the intestinal epithelium.
\end{abstract}

Keywords: probiotic; survival; vegetable beverage; gastrointestinal survival

\section{Introduction}

Functional foods have aroused great interest from consumers. Such foods act in the prevention and/or reduction in diseases related to nutritional, physical, and mental wellbeing [1]. The probiotic products belong to this functional foods category, which some authors call non-nutrient bioactive [2].

Probiotics are live microorganisms that promote beneficial effects to the consumer when administered in adequate amounts [3]. Several benefits have been attributed to the consumption of probiotic foods, such as improved lactose metabolism [4], prevention of intestinal tract infections, cholesterol reduction, increased immunity, stimulating increased absorption of calcium, improved protein digestibility, and prevention of cardiovascular diseases [5-9]. However, for the achievement of these benefits by the consumer, the food must have a probiotic population of at least $10^{6}$ to $10^{9} \mathrm{CFU} / \mathrm{g}$ at the time of food consumption [10].

The probiotic bacteria in food systems must survive passage through the gastric juice and persist in the gut and provide benefits to the host's health [11]. For this reason, strains of lactic acid bacteria should be subjected to preliminary screening tests to select strains that have tolerances to gastric and pancreatic conditions in in vitro tests.

The low $\mathrm{pH}$ of the stomach and the antimicrobial action of pepsin provide a barrier against the entry of bacteria into the intestine. The $\mathrm{pH}$ of the stomach presents a variation, 
which is usually influenced by the type of ingested food. Typically, the $\mathrm{pH}$ of gastric juice is around 2.5 to 3.5. The stomach's permanence time is dependent on the type of food. Solid foods have a permanence time in the stomach between 2 to $4 \mathrm{~h}$. However, liquid foods remain on an empty stomach for less time [12].

Another barrier that probiotic bacteria must survive is the small intestine. Adverse conditions in the small intestine include the presence of bile salts and pancreatin. The transit time of food through the small intestine is usually between 1 to $4 \mathrm{~h}$. The $\mathrm{pH}$ of the small intestine is around $\mathrm{pH} 8.0$ [12].

Due to historical and technological reasons and the nutritional value of milk, probiotic microorganisms are often incorporated into dairy-based foods [13]. Several studies have proven the protective effect of dairy foods on probiotic lactic acid bacteria exposed to conditions that prevail in the gastrointestinal tract [14-18]. However, there is a growing interest on the part of some consumers, especially people with dietary restrictions, in the development of non-dairy probiotic products [19-21]. Such dietary restrictions include people with lactose intolerance, who are allergic to milk protein, or adept to veganism [22]. Because of this demand, some researchers have directed their studies to develop non-dairybased probiotic products [23-27].

Fruit juices have been the target of many researchers to develop probiotic fermented beverages $[13,25,28,29]$. However, maintaining the viability of probiotic cultures in fruit juices has been difficult. These products have low $\mathrm{pH}$, high concentration of dissolved $\mathrm{O}_{2}$, and insufficient amino acids and peptides [30].

An alternative to fruit juices could be the application of legumes in the production of fermented beverages. Chickpea (Cicer arietinum L.) is the second most widely leguminous plant grown globally [31]. It is considered an excellent component in the human diet due to the content of proteins, fibers, starch, and bioactive compounds [32]. Chickpea is considered a suitable source of protein due to the excellent balance in amino acid composition, high bioavailability, and low anti-nutritional factors [33]. In addition to these characteristics, beverages made with chickpeas have shown excellent fermentability by lactic acid bacteria [34,35]. However, studies on the use of chickpeas in the production of fermented beverages are still very scarce, mainly regarding the protective function of chickpea beverages in the viability of probiotic cultures exposed to the conditions prevailing in the gastrointestinal tract.

Given the above, the objective of this study was to evaluate in a static in vitro digestion model the survival of Lactobacillus paracasei subsp. paracasei LBC 81 in fermented chickpea and coconut beverage, as well as the impact of refrigerated storage of the fermented beverage on the survival of the strain.

\section{Materials and Methods}

\subsection{Chickpea and Coconut Beverage Production}

Chickpea extract: The chickpeas used were BRS Toro FLIP 06-155C, produced in 2018 in the experimental area of EMBRAPA HORTALICAS, Federal District, Brazil. A quantity of $1252 \mathrm{~g}$ of chickpeas was rehydrated in potable water for $12 \mathrm{~h}$. Later, it was submitted to the cooking process in a domestic pressure cooker (Rochedo ${ }^{\circledR}$, Brazil) at $120{ }^{\circ} \mathrm{C}$ and $2.0 \mathrm{~atm}$ for $20 \mathrm{~min}$ after the pressure started. According to the procedure established by Rincon et al., the cooked chickpeas were used to obtain the chickpea extract [31].

Coconut extract: The coconut extract was prepared according to the procedure described by Rincon et al. [36]. The ripe coconut was purchased at a local supermarket in Brasilia, Brazil. The coconut (shell-inner hard coat and meat-solid endosperm) was processed in a blender (Philco ${ }^{\circledR}$, model PH900, Manaus, Brazil) and water for $3.0 \mathrm{~min}$ and strained in tissue to obtain the coconut extract.

Chickpea and coconut beverage: An amount of $10 \%$ of the coconut extract was added to $90 \%$ of the chickpea extract. In $300 \mathrm{~mL}$ of the beverage, $10 \%$ sugar was added, and then the beverage was autoclaved at $121^{\circ} \mathrm{C}$ for $15 \mathrm{~min}$. 


\subsection{Production of Fermented Chickpea and Coconut Beverage}

The preparation of the fermented beverage was carried out according to the protocol described by Mesquita et al. [35]. Lactobacillus paracasei subsp. paracasei LBC 81 was used to produce the fermented beverage. The culture was grown first in MRS and incubated at $37^{\circ} \mathrm{C}$ for $16 \mathrm{~h}$. An inoculum of $4.0 \%$ of the active culture, containing approximately $10^{8}$ $\mathrm{CFU} / \mathrm{mL}$, was added to $300 \mathrm{~mL}$ of the chickpea and coconut beverage and was immediately incubated at $37^{\circ} \mathrm{C}$ for $6 \mathrm{~h}$. After fermentation, the beverage was stored at $4{ }^{\circ} \mathrm{C}$ for 8 days in a climatic chamber (model MA 415 Marconi, Piracicaba, Brazil).

\subsection{Survival to Gastro-Intestinal Simulated Stresses}

The fermented beverage of chickpea and coconut was subjected to gastric juice, pancreatic juice, and sequential exposure to gastric and pancreatic juice. The following controls were used in the experiment to evaluate the protective effect of fermented chickpea and coconut beverage in L. paracasei LBC 81 against gastrointestinal stress conditions:

(i) Suspension of cells in saline: the active culture of L. paracasei LBC 81 was inoculated in $0.85 \%$ saline solution with $\mathrm{pH}$ adjusted to 6.5 . Culture inoculum $(4.0 \%)$ containing approximately $10^{8} \mathrm{CFU} / \mathrm{mL}$ for inoculation in saline solution. The suspension of cells in saline was used as control 1 of the experiment to evaluate the protective effect of food on the viability of L. paracasei LBC 81.

(ii) Cell suspension in chickpea and coconut beverage: the active culture of $L$. paracasei LBC 81 was inoculated in chickpea and coconut beverage. Culture inoculum $(4.0 \%)$ containing approximately $10^{8} \mathrm{CFU} / \mathrm{mL}$ was used for inoculation in chickpea and coconut beverage. The cell suspension in the chickpea and coconut beverage was used as control 2 of the experiment to evaluate the effect of fermentation on the viability of L. paracasei LBC 81.

\subsubsection{Exposure to Gastro-Intestinal Simulated Stresses}

Gastric juice: Synthetic gastric juice was prepared according to the protocol of BautistaGallego et al. [37]. Gastric juice was prepared with $\mathrm{NaCl}(2.05 \mathrm{~g} / \mathrm{L}), \mathrm{KH}_{2} \mathrm{PO}_{4}(0.60 \mathrm{~g} / \mathrm{L})$, $\mathrm{CaCl}_{2}(0.11 \mathrm{~g} / \mathrm{L})$, and $\mathrm{KCl}(0.37 \mathrm{~g} / \mathrm{L})$. The $\mathrm{pH}$ of the solution was adjusted to 2.0 with $1 \mathrm{M} \mathrm{HCl}$, and later it was autoclaved at $121^{\circ} \mathrm{C}$ for $15 \mathrm{~min}$. Pepsin $(0.0133 \mathrm{~g} / \mathrm{L})(\mathrm{Chemical}$ dynamics, Indaiatuba, Brazil) and lysozyme ( $0.01 \mathrm{~g} / \mathrm{L})$ (Sigma-Aldrich, St Louis, MO, USA) were added to this solution. A $100 \mu \mathrm{L}$ aliquot of the fermented chickpea and coconut beverage was added to $900 \mu \mathrm{L}$ of the gastric juice, then incubated at $37^{\circ} \mathrm{C}$ for $3 \mathrm{~h}$ in static conditions. The suspensions of cells in saline (control 1) and in chickpea and coconut beverage (control 2) were submitted to the same conditions.

Pancreatic juice: The synthetic pancreatic juice was prepared according to the protocol of Bautista-Gallego et al. [37]. The synthetic pancreatic juice was prepared with dibasic sodium phosphate heptahydrate $(50.81 \mathrm{~g} / \mathrm{L})$ and $\mathrm{NaCl}(8.50 \mathrm{~g} / \mathrm{L})$. Bile salts $(3.00 \mathrm{~g} / \mathrm{L})$ (Sigma-Aldrich) were added to the solution, and the $\mathrm{pH}$ was adjusted to 8.0. The solution was autoclaved at $121^{\circ} \mathrm{C}$ for $15 \mathrm{~min}$, and $0.10 \mathrm{~g} / \mathrm{L}$ of pancreatin (Sigma-Aldrich) was added. A $100 \mu \mathrm{L}$ aliquot of the fermented chickpea and coconut beverage was added to $900 \mu \mathrm{L}$ of the pancreatic juice, then incubated at $37^{\circ} \mathrm{C}$ for $4 \mathrm{~h}$ in static conditions. The suspensions of cells in saline (control 1) and in chickpea and coconut drink (control 2) were submitted to the same conditions.

Sequential exposure to gastric and pancreatic juice: The procedure was performed as described in item 2.3 regarding exposure to gastric and pancreatic juice, except that after exposure to gastric juice for $3 \mathrm{~h}$, the treatments were also exposed to pancreatic juice for $4 \mathrm{~h}$.

\subsubsection{Determination of Survival}

After the fermented chickpea and coconut beverage and its controls (1 and 2) were exposed to gastric and pancreatic conditions, the survival of $L$. paracasei LBC 81 was determined. After the incubation period, the treatments were subjected to centrifugation $\left(2655 \times g, 4{ }^{\circ} \mathrm{C}, 5 \mathrm{~min}\right)$, and the obtained cell pellet was washed with saline and later cen- 
trifuged under the same mentioned conditions. The obtained cell pellet was resuspended in $900 \mu \mathrm{L}$ of saline solution and subsequently subjected to serial dilutions. The selected dilutions were plated in Petri dishes containing MRS agar culture medium and immediately incubated in aerobic conditions at $37^{\circ} \mathrm{C}$ for $48 \mathrm{~h}$. The colony-forming unit (CFU) number was determined after the incubation period, expressed in log CFUmL. From the $\log \mathrm{CFU} / \mathrm{mL}$ the percentage of survival was determined. The survival percentage was determined according to the equation below (Equation (1)):

$$
\text { Survival }(\%)=\mathrm{N}_{1} / \mathrm{N}_{0} \times 100 \%
$$

where $\mathrm{N}_{1}(\log \mathrm{CFU} / \mathrm{mL})$ represents the viability after exposure to gastrointestinal stress conditions in vitro, and $\mathrm{N}_{0}(\log \mathrm{CFU} / \mathrm{mL})$ represents the viability before exposure to gastrointestinal stress conditions in vitro.

Figure 1 describes the production of the fermented chickpea and coconut beverage as well as the survival experiments to gastrointestinal simulated stresses.

Production of fermented chickpea and coconut beverage

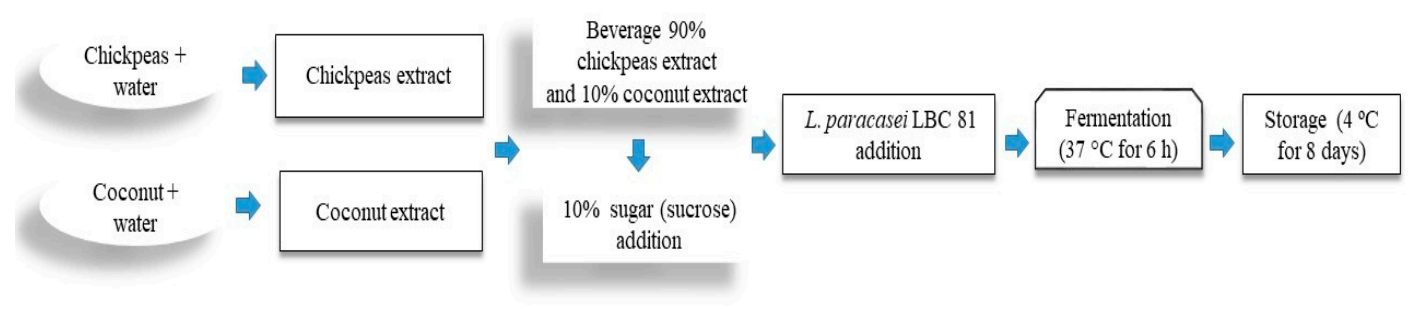

Survival to gastro-intestinal simulated stresses

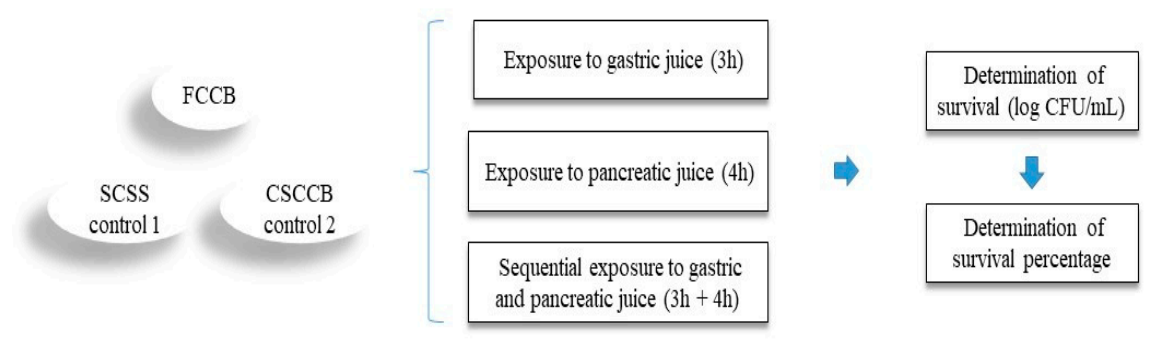

Figure 1. Chickpea and coconut production steps and survival experiments to gastrointestinal simulated stresses.

\subsection{Statistical Analysis}

For survival analysis of L. paracasei LBC 81 after simulated gastric conditions, pancreatic conditions, and sequential exposure to gastric and pancreatic juice, treatments with fermented beverage were considered, compared to cell suspension in saline (control 1) and cell suspension in chickpea beverage (control 2). ANOVA with subsequent Tukey test at $5 \%$ probability was performed. The graphics were generated using SigmaPlot v.12 software (San Jose, CA, United States). For each experiment, three repetitions were considered.

\section{Results}

3.1. Survival of Simulated Gastrointestinal Tract of Lactobacillus paracasei subsp. paracasei LBC 81 in Fermented Beverage

The survival of $L$. paracasei LBC 81 in fermented chickpea and coconut beverage was determined after exposure to gastric and pancreatic conditions simulated in vitro (Figure 2). The survival of L. paracasei LBC 81 in the fermented beverage, after exposure for $3 \mathrm{~h}$ to gastric juice, was $99.47 \pm 2.05 \%$ (Figure $2 \mathrm{~A}$ ). This survival percentage was significantly 
$(p<0.05)$ higher than that of the cell suspension in saline solution and chickpea and coconut beverage.

A

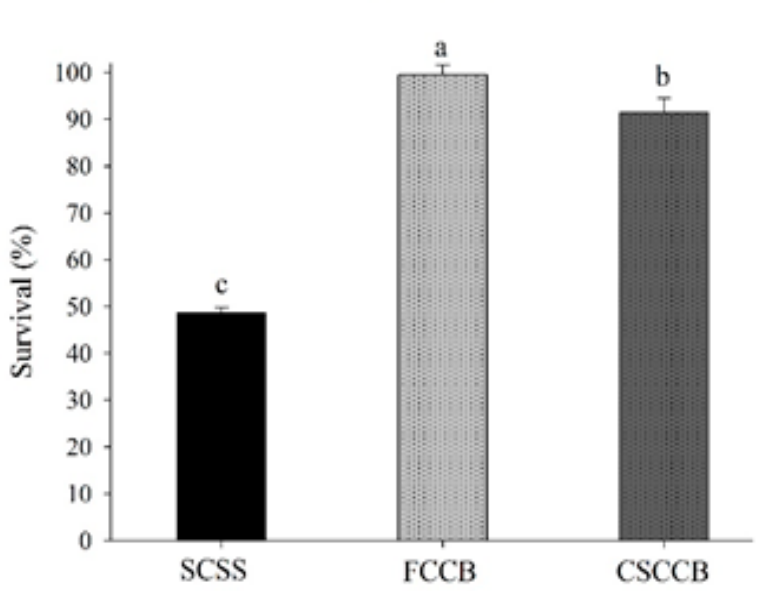

B Pancreatic juice

C Sequential exposure to gastric and pancreatic juices
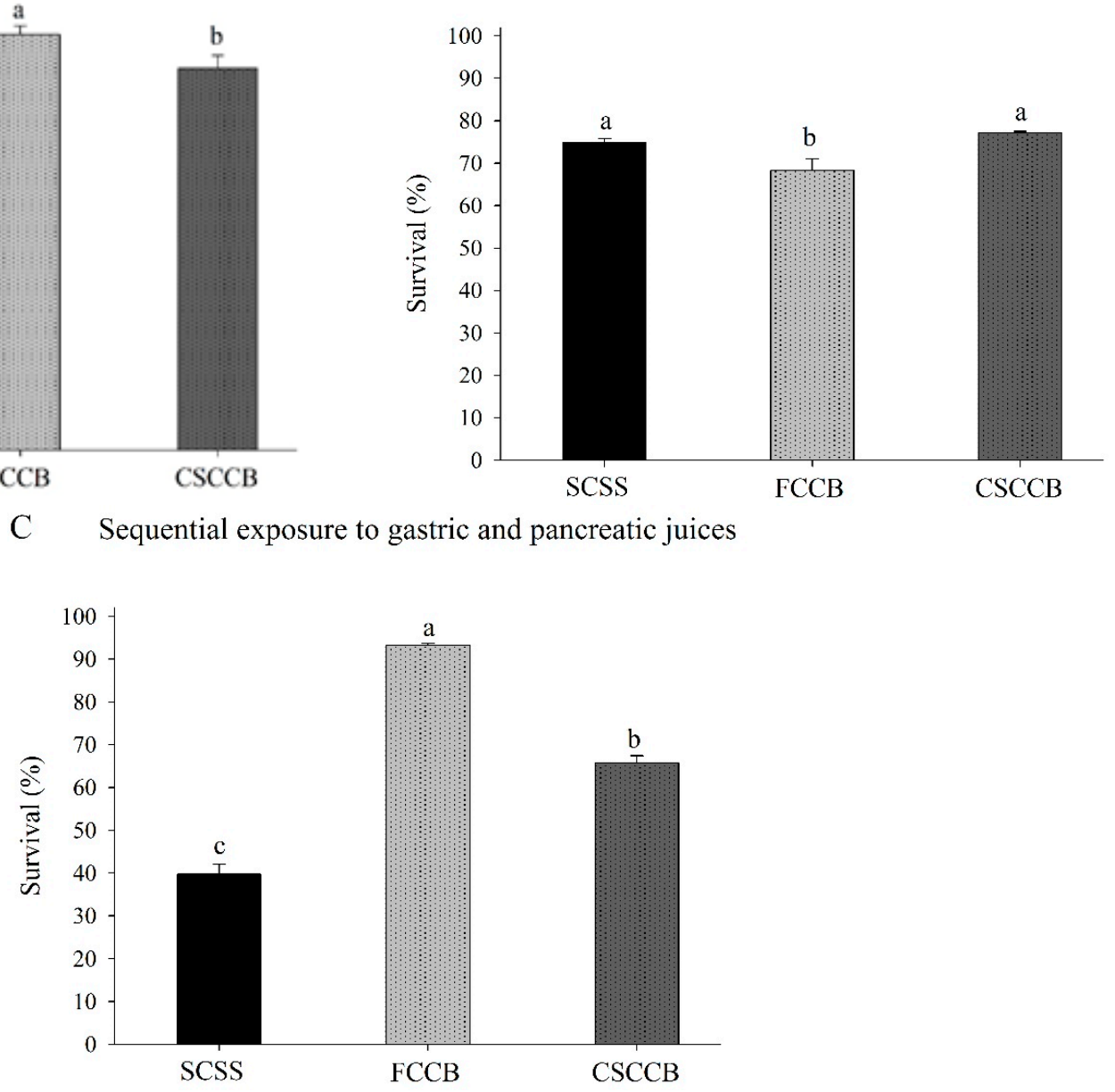

Figure 2. Survival (\%) of L. paracasei LBC 81 in the suspension of cells in saline solution (SCSS), fermented chickpea and coconut beverage (FCCB), and cell suspension in chickpea and coconut beverage (CSCCB), after exposure to (A) simulated gastric juice, (B) simulated pancreatic juice, and (C) sequential exposure to gastric and pancreatic juice. Different lowercase letters differ significantly by the Tukey test at $5 \%$ probability. $n=$ three repetitions.

The $\mathrm{pH}$ of the fermented beverage, the cell suspension in saline, and the cell suspension in the chickpea and coconut beverage were $4.10 \pm 0.03,5.53 \pm 0.21$, and $5.20 \pm 0.19$, respectively. The greater survival of $L$. paracase LBC 81 in the fermented beverage may be related to the lower $\mathrm{pH}$ value. It is possible that during the chickpea and coconut beverage fermentation process, the strain has adapted to low $\mathrm{pH}$ conditions, which may have induced the activation of resistance mechanisms facing exposure to simulated gastric juice. In addition, it is observed that the presence of food was a protective factor for $L$. paracasei LBC 81 against exposure to simulated gastric juice, given the lower survival of the strain found in the suspension of cells in saline solution.

The survival percentage of $L$. paracasei in the fermented beverage, after exposure for $4 \mathrm{~h}$ to pancreatic juice, was $68.26 \pm 2.77$ (Figure 2B). The survival of L. paracasei in the fermented beverage was significantly $(p<0.05)$ lower than that in cell suspensions in saline solution or chickpea and coconut beverage. The low $\mathrm{pH}$ of the fermented beverage may have contributed to the sensitivity of $L$. paracasei to pancreatic juice since, in cell suspensions, a higher percentage of survival was observed. In addition, it is observed that the presence of the food was not responsible for protecting the action of pancreatic juice on 
L. paracasei. The suspension of cells in saline solution did not show a significant difference $(p>0.05)$ concerning the suspension of cells in the chickpea beverage. It is observed that the suspension of cells in saline presents more tolerance to pancreatic juice (Figure 2B) than gastric juice (Figure 2A).

The percentage of survival of $L$. paracasei in the fermented beverage after sequential exposure to gastric and pancreatic juice was $93.21+0.43 \%$ (Figure 2C). The survival of L. paracasei in the fermented beverage after sequential exposure to gastric and pancreatic juice was significantly $(p<0.05)$ higher than that in the two cell suspensions. However, cell suspension in the chickpea and coconut beverage was significantly $(p<0.05)$ higher than that in cell suspension in saline.

In sequential exposure to gastric and pancreatic juice, it was possible to observe the protective effect of the chickpea beverage on the viability of $L$. paracasei. However, this protective effect of the chickpea beverage may be associated with the protection of gastric juice and not pancreatic juice. When all treatments were exposed only to pancreatic juice, it was not possible to observe the protective effect of the food on the viability of $L$. paracasei since there was no significant difference $(p>0.05)$ between cell suspensions, and a lower survival percentage was observed in the fermented beverage. When all treatments were exposed to gastric juice, it was possible to observe significant differences $(p<0.05)$, with higher percentages of strain survival in the fermented beverage and in the cell suspension in the chickpea and coconut beverage. It confirms again that the protective action of the chickpea and coconut beverage against $L$. paracase $\operatorname{LBC} 81$ is associated with previous exposure in an acidic medium.

3.2. Survival of Simulated Gastrointestinal Tract of Lactobacillus paracasei subsp. paracasei LBC 81 in Fermented Beverage Stored under Refrigeration

The survival percentage of $L$. paracasei in a fermented beverage with 8 days of refrigerated storage at $4{ }^{\circ} \mathrm{C}$, when exposed to gastric juice, pancreatic juice, or sequential exposure to gastric and pancreatic juice, was not significantly affected $(p>0.05)$ (Table 1$)$. With 1 day of refrigerated storage, the $\mathrm{pH}$ of the fermented beverage was $4.10 \pm 0.03$. After 8 days of refrigerated storage, the $\mathrm{pH}$ of the fermented beverage decreased to $\mathrm{pH} 3.18 \pm 0.10$. Even with the event of post-acidification during refrigerated storage, the viability of $L$. paracasei in the fermented beverage was not compromised after being exposed to gastric juice, pancreatic juice, or sequential exposure to gastric and pancreatic juice.

Table 1. Survival (\%) of Lactobacillus paracasei subsp. paracasei LBC 81 during refrigerated storage at $4{ }^{\circ} \mathrm{C}$ of FCCB and CSCCB, after simulated gastrointestinal conditions.

\begin{tabular}{|c|c|c|c|c|}
\hline \multirow[b]{2}{*}{ Time (day) } & \multicolumn{4}{|c|}{ Treatment } \\
\hline & FCCB $^{*}$ & $\mathrm{pH}^{* *}$ & $\mathrm{CSCCB}^{* * *}$ & $\mathrm{pH}^{* * * *}$ \\
\hline \multicolumn{5}{|c|}{ Gastric juice } \\
\hline 1 & $99.47 \pm 2.05 \mathrm{aA}$ & $4.10 \pm 0.03$ & $91.46 \pm 3.02 b B$ & $5.53 \pm 0.21$ \\
\hline 8 & $100.11 \pm 1.45 \mathrm{aA}$ & $3.18 \pm 0.10$ & $99.05 \pm 0.61 \mathrm{aA}$ & $4.06 \pm 0.04$ \\
\hline \multicolumn{5}{|c|}{ Pancreatic juice } \\
\hline 1 & $68.26 \pm 2.77 \mathrm{aB}$ & $4.10 \pm 0.03$ & $77.21 \pm 0.28 \mathrm{aA}$ & $5.53 \pm 0.21$ \\
\hline 8 & $72.19 \pm 7.86 \mathrm{aA}$ & $3.18 \pm 0.10$ & $52.42 \pm 4.38 \mathrm{bB}$ & $4.06 \pm 0.04$ \\
\hline \multicolumn{5}{|c|}{ Sequential exposure to gastric and pancreatic juice } \\
\hline 1 & $93.21 \pm 0.43 \mathrm{aA}$ & $4.10 \pm 0.03$ & $65.67 \pm 1.75 b B$ & $5.53 \pm 0.21$ \\
\hline 8 & $96.31 \pm 3.47 \mathrm{aA}$ & $3.18 \pm 0.10$ & $86.89 \pm 0.68 \mathrm{aB}$ & $4.06 \pm 0.04$ \\
\hline
\end{tabular}

Means followed by the same lowercase letter in the columns and uppercase in the rows do not differ statistically by the Tukey test at $5 \%$ probability. $n=$ three repetitions. FCCB*: Fermented chickpea and coconut Beverage. $\mathrm{pH}^{* *}$ : $\mathrm{pH}$ of FCCB during refrigerated storage. CSCCB*** Cell suspension in chickpea and coconut beverage. $\mathrm{pH}^{* * * *}: \mathrm{pH}$ of CSCCB during refrigerated storage.

In the suspension of cells in the chickpea and coconut beverage, under different conditions, exposure to gastric juice, pancreatic juice, or sequential exposure to gastric and pancreatic juice, the survival percentage of $L$. paracasei was affected by storage for 
8 days in refrigerated conditions. The suspension of cells in the chickpea and coconut beverage stored for 8 days under refrigeration conditions showed a significant increase $(p<0.05)$ in survival after exposure to gastric juice. The decrease in the $\mathrm{pH}$ of the cell suspension in the chickpea and coconut beverage during storage contributed to the increase in survival after the exposure to gastric juice. The same behavior was observed when the cell suspension was exposed to a sequential condition of gastric and pancreatic juice. Only after the exposure to pancreatic juice was there a significant reduction $(p<0.05)$ in the survival percentage.

The cell suspension in the chickpea and coconut beverage with 1 day of refrigerated storage showed a $\mathrm{pH}$ of $5.53 \pm 0.21$. After 8 days of refrigerated storage, the $\mathrm{pH}$ decreased to $4.06 \pm 0.04$. Compared to the fermented beverage with 1 day of refrigerated storage, the suspension of cells in the chickpea and coconut beverage with 8 days of refrigerated storage became more tolerant to gastric juice and sequential exposure to gastric and pancreatic juice. At the same time, this suspension became more sensitive to exposure to pancreatic juice.

\section{Discussion}

In the fermented beverage, L. paracasei has probably adapted to this low $\mathrm{pH}$ condition, which may have caused the induction of resistance mechanisms to more lethal conditions, such as the conditions prevailing in gastric juice. Several factors may have contributed to the increase in the tolerance of L. paracasei in the fermented beverage after exposure to gastric juice. Mechanisms such as the arginine dihydrolase system, proton pump (F1-F0ATPase), amino acid decarboxylation, and protection and repair of cellular macromolecules (DNA, RNA, and proteins) have been identified in some strains of lactic acid bacteria. Such mechanisms are associated with the highest percentage of survival in acid stress conditions [38-40]. It is important to note that chickpeas contain free amino acids, among several amino acids is arginine [41,42]. It is possible that L. paracasei LBC 81 transported arginine to its cytoplasm. Therefore, mechanisms such as the decarboxylation of amino acids and the arginine dihydrolase system have protected from damage caused by the acidic medium.

A similar result regarding the survival of L. paracasei in a fermented beverage after exposure to gastric juice was also verified by Elizaquível et al. [43]. These authors found that lactic acid bacteria in orange juice with a low $\mathrm{pH}$ (3.80) are more tolerant of gastric conditions than bacteria incorporated in yogurt ( $\mathrm{pH} 4.7$ ) and milk beverage with orange juice $(\mathrm{pH} 4,3)$. According to the authors, orange juice may have induced a greater tolerance to gastric juice.

The chemical constituents and ingredients used in preparing the chickpea and coconut beverage probably played an important role in the high percentage of L. paracasei survival in the fermented beverage. The survival of $L$. paracase $i$ in cell suspension in chickpea and coconut beverage was significantly $(p<0.05)$ higher than that of the cell suspension in saline solution. This result confirms the importance of food as a protective barrier to gastric juice. Casarotti et al. [44] observed a marked reduction in the viability of Lactobacillus acidophilus in fermented milk after exposure to gastric juice. However, they observed that the preparation of fermented milk with apple, banana, or grape flour accentuated the survival of L. acidophilus after exposure to gastric juice. Kocer and Unal [45] observed that the addition of inulin in fermented milk increased the survival of L. acidophilous after exposure to gastric juice.

Carbohydrates correspond to the most abundant compounds that make up chickpeas. According to Faridy et al. [31], chickpeas have 62-70\% carbohydrates, containing mainly oligosaccharides such as raffinose, stachyose, and verbascose, and polysaccharides such as starch and dietary fiber. These chemical constituents probably played an important role as a physical barrier to protect the action of gastric juice on L. paracasei. According to Casaroti et al. [44], inulin, a polysaccharide, contains small aggregates that can act as a physical barrier to protect against acid and bile salts to the microbial cell. In addition, the ability to produce extracellular polysaccharides by lactic acid bacteria has been associated 
with increased tolerance to gastric juice. However, the increase in tolerance to gastric juice is also related to the carbon source available in the medium $[46,47]$.

Several studies have shown that probiotic microorganisms not inserted in food or in some type of coating have a high reduction in survival percentage after exposure to gastric juice [48-50]. In addition to protecting a physical barrier to the action of the acid medium or the presence of bile salts on microorganisms, it has the function of raising the $\mathrm{pH}$ of gastric juice. The addition of fermented chickpea and coconut drinks to gastric juice increased the $\mathrm{pH}$ of gastric juice. The gastric juice was prepared with a $\mathrm{pH}$ adjusted to 2.0 , and when the fermented chickpea and coconut beverage was added, the $\mathrm{pH}$ increased to 2.9. Such increase in $\mathrm{pH}$ of gastric juice should also be considered one of the factors responsible for the high percentage of survival of L. paracasei in the fermented chickpea beverage.

Bile salts are one of the components of pancreatic juice that most compromises the viability of microorganisms [38-40]. Bile salts can affect phospholipids and membrane proteins and the modification of cellular homeostasis and stability of macromolecules [51]. The loss of viability of L. paracasei after exposure to pancreatic juice was verified in all treatments. Given the results, L. paracasei likely has an intrinsic tolerance to pancreatic juice since the food was not responsible for maintaining viability after exposure to pancreatic juice. According to Begley et al. [51], the tolerance of Gram-positive bacteria to bile salts is a strain-dependent characteristic and cannot be generalized in terms of species. The enzyme bile salt hydrolase (BSH) is present in some probiotic lactic acid bacteria, and its action is essential to decrease the toxicity of bile salts to probiotic bacteria [40].

Unlike the results achieved in this study, some authors have found that food is important to enhance probiotic bacteria's viability against bile salts' action $[18,44,45]$. Likely, the chickpea and coconut beverage chemical constituents could not effectively reduce the action of pancreatic juice on $L$. paracasei.

The greater survival of $L$. paracasei in the fermented beverage can be justified by the fact that it adapts to the acidic conditions of the fermented beverage, which consequently caused it to resist a lower $\mathrm{pH}$ condition. Some mechanisms may have been activated when exposed to gastric juice that confers greater resistance to pancreatic juice. According to Picard et al. [52], BSH, consequently reducing the toxicity to probiotic bacteria, is activated during its transit through the gastrointestinal tract. It is possible that during the exposure to gastric juice, this enzyme was activated significantly and consequently provided greater protection to L. paracasei from the action of bile salts. However, the activation of BSH and other mechanisms was more active in the fermented beverage.

Bedani et al. [53] observed that in L. acidophilus La-5 and Bifidobacterium animalis Bb-12 strains incorporated in soy yogurt, the survival to gastrointestinal conditions was not affected by refrigerated storage. Wang et al. [50] reported that the gastric resistance ( $\mathrm{pH} 2.0)$ of Lactobacillus casei Zhang was lower during the storage period (28 days) in fermented milk but not in fermented soy milk. Other authors found that resistance to gastrointestinal conditions, of probiotic lactic acid bacteria, in fermented beverages is affected by the condition of refrigerated storage $[1,44,45,54]$.

Given these results, we observed that the decrease in the $\mathrm{pH}$ of the cell suspension in the chickpea and coconut beverage during 8 days of storage was responsible for the increased tolerance to gastric juice and the sequential exposure to gastric and pancreatic juice. This decrease in $\mathrm{pH}$ was also responsible for the greater sensitivity of L. paracasei to gastric juice. The results obtained from the cell suspension in the chickpea and coconut beverage with 8 days of refrigerated storage show similar physiological behaviors of the fermented beverage stored at 1 day under refrigeration.

\section{Conclusions}

This study found that chickpea and coconut fermented beverage caused greater protection, compared to only the cell suspension in the chickpea and coconut beverage, to sequential exposure to gastric and pancreatic juice. In addition, the fermented beverage stored for 8 days under refrigeration did not affect the survival of L. paracasei LBC 81 after 
exposure to gastric and pancreatic conditions. The results conclude that the fermented beverage of chickpeas and coconut is an excellent carrier for L. paracasei LBC 81, capable of enhancing survival to gastrointestinal conditions and consequently ensuring that many viable cells reach the intestinal epithelium.

Author Contributions: Conceptualization, E.d.S.L., M.C.M. and R.B.A.B.; methodology, E.d.S.L., M.C.M.; formal analysis, E.R.d.A.; investigation M.C.M.; resources, E.d.S.L.; writing—original draft preparation, E.d.S.L., M.C.M.; writing—review and editing, E.d.S.L., E.R.d.A.; R.B.A.B.; supervision, E.d.S.L.; project administration, E.d.S.L.; R.B.A.B. All authors have read and agreed to the published version of the manuscript.

Funding: This research received no external funding.

Data Availability Statement: Not applicable.

Acknowledgments: We thank the Coordenação de Aperfeiçoamento de Pessoal de Nível Superior (CAPES) of Brazil for its support in the form of a scholarship and the Fundação de Apoio à Pesquisa do Distrito Federal (FAPDF) for analysis materials.

Conflicts of Interest: The authors declare no conflict of interest.

\section{References}

1. Saarela, M.; Lähteenmäki, L.; Crittenden, R.; Salminen, S.; Mattila-Sandholm, T. Gut bacteria and health foods-the European perspective. Int. J. Food Microbiol. 2002, 78, 99-117. [CrossRef]

2. Da Silva, B.V.; Barreira, J.C.M.; Oliveira, M.B.P.P. Natural phytochemicals and probiotics as bioactive ingredients for functional foods: Extraction, biochemistry and protected-delivery technologies. Trends Food Sci. Technol. 2016, 50, 144-158. [CrossRef]

3. Food and Agriculture Organization of the United Nations/ World Health Organization (FAO/WHO). Guidelines for the Evaluation of Probiotics in Food: Report of a Joint FAO/WHO Working Group; FAO: Rome, Italy; WHO: Geneva, Switzerland, 2002.

4. Jiang, X.Y.; Li, X.H.; Zhang, B.S.; Ren, D.M. Isolation and identification of nitrite-degrading lactic acid bacteria from traditional pickled vegetables. China Brew. 2008, 1, 13-16.

5. Homayouni, A.; Payahoo, L.; Azizi, A. Effects of Probiotics on Lipid Profile: A Review. Am. J. Food Technol. 2012, 7, 251-265. [CrossRef]

6. Sanders, M.E.; Tompkins, T.; Heimbach, J.T.; Kolida, S. Weight of evidence needed to substantiate a health effect for probiotics and prebiotics: Regulatory considerations in Canada, E.U., and U.S. Eur. J. Nutr. 2005, 44, 303-310. [CrossRef]

7. Suvarna, J.V.C.; Boby, V.U. Probiotics in human health: A current assessment. Curr. Sci. 2004, 88, $1744-1748$.

8. Parvez, S.; Malik, K.A.; Ah Kang, S.; Kim, H.Y. Probiotics and their fermented food products are beneficial for health. J. Appl. Microbiol. 2006, 100, 1171-1185. [CrossRef]

9. Oxman, T.; Shapira, M.; Klein, R.; Avazov, N.; Rabinowitz, B. Oral administration of Lactobacillus induces cardioprotection. J. Altern. Complement. Med. 2001, 7, 345-354. [CrossRef] [PubMed]

10. Nazzaro, F.; Fratianni, F.; Nicolaus, B.; Poli, A.; Orlando, P. The prebiotic source influences the growth, biochemical features and survival under simulated gastrointestinal conditions of the probiotic Lactobacillus acidophilus. Anaerobe 2012, 18, 280-285. [CrossRef] [PubMed]

11. Terpou, A.; Papadaki, A.; Lappa, I.K.; Kachrimanidou, V.L.; Bosnea, A.; Kopsahelis, N. Probiotics in Food Systems: Significance and Emerging Strategies Towards Improved Viability and Delivery of Enhanced Beneficial Value. Nutrients 2019, $11,1591$. [CrossRef]

12. Huang, Y.; Adams, M.C. In vitro assessment of the upper gastrointestinal tolerance of potential probiotic dairy propionibacteria. Int. J Food Microbiol. 2004, 91, 253-260. [CrossRef]

13. Nguyen, B.T.; Bujna, E.; Fekete, N.; Tran, A.T.M.; Rezessy-Szabo, J.M.; Prasad, R.; Nguyen, Q.D. Probiotic beverage from pineapple juice fermented with Lactobacillus and Bifidobacterium strains. Front. Nutr. 2019, 6, 1-7. [CrossRef]

14. Madureira, A.R.; Amorim, M.; Gomes, A.M.; Pintado, M.E.; Malcata, F.X. Protective effect of whey cheese matrix on probiotic strains exposed to simulated gastrointestinal conditions. Food Res. Int. 2011, 44, 465-470. [CrossRef]

15. Araújo, E.A.; de Carvalho, A.F.; Leandro, E.S.; Furtado, M.M.; de Moraes, C.A. Development of a symbiotic cottage cheese added with Lactobacillus delbrueckii UFV H2b20 and inulin. J. Funct. Foods 2010, 2, 85-89. [CrossRef]

16. Dos Santos Leandro, E.; de Araújo, E.A.; da Conceição, L.L.; de Moraes, C.A.; de Carvalho, A.F. Survival of Lactobacillus delbrueckii UFV H2b20 in ice cream produced with different fat levels and after submission to stress acid and bile salts. J. Funct. Foods 2013, 5, 503-507. [CrossRef]

17. De Oliveira Vogado, C.; dos Santos Leandro, E.; de Alencar, E.R.; Ginani, V.C.; Zandonadi, R.P. Survival of Lactobacillus paracasei subsp. paracasei LBC 81 in Fermented Milk Enriched with Green Banana Pulp Under Acid Stress and in the Presence of Bile Salts. Probiotics Antimicrob. Proteins 2020, 12, 320-324. [PubMed] 
18. Da Silva, T.M.S.; Piazentin, A.C.M.; Mendonça, C.M.N.; Converti, A.; Bogsan, C.S.B.; Mora, D.; de Souza Oliveira, R.P. Buffalo milk increases viability and resistance of probiotic bacteria in dairy beverages under in vitro simulated gastrointestinal conditions. J. Dairy Sci. 2020, 103, 7890-7897. [CrossRef]

19. Kandylis, P.; Pissaridi, K.; Bekatorou, A.; Kanellaki, M.; Koutinas, A.A. Dairy and non-dairy probiotic beverages. Curr. Opin. Food Sci. 2016, 7, 58-63. [CrossRef]

20. Vilela, A.; Cosme, F.; Inês, A. Wine and Non-Dairy Fermented Beverages: A Novel Source of Pro- and Prebiotics. Fermentation 2020, 6, 113. [CrossRef]

21. Aspri, M.; Papademas, P.; Tsaltas, D. Review on Non-Dairy Probiotics and Your Use in Non-Dairy Based Products. Fermentation 2020, 6, 30. [CrossRef]

22. Shori, A.B. Influence of food matrix on the viability of probiotic bacteria: A review based on dairy and non-dairy beverages. Food Biosci. 2016, 13, 1-8. [CrossRef]

23. Da Costa, M.R.; de Alencar, E.R.; Dos Santos Leandro, E.; Mendonça, M.A.; de Souza Ferreira, W.F. Characterization of the kefir beverage produced from yam (Colocasia esculenta L.), sesame seed (Sesamum indicum L.) and bean (Phaseolus vulgaris L.) extracts. J. Food. Sci. Technol. 2018, 55, 4851-4858. [CrossRef] [PubMed]

24. Barbosa, M.L.S.; de Alencar, E.R.; dos Santos Leandro, E.; Borges, R.M.; Mendonça, M.A.; de Souza Ferreira, W.F. Characterization of fermented beverages made with soybean and Brazil nut hydrosoluble extracts. Int. J. Gastron. Food Sci. 2020, $21,100228$. [CrossRef]

25. De Oliveira Ribeiro, A.P.; dos Santos Gomes, F.; dos Santos, K.M.O.; da Matta, V.M.; de Grandi Castro Freitas de Sá, D.; de Araujo Santiago, M.C.P.; Conte, C.; de Oliveira Costa, S.D.; de Oliveira Ribeiro, L.; de Oliveira Godoy, R.L.; et al. Development of a probiotic non-fermented blend beverage with juçara fruit: Effect of the matrix on probiotic viability and survival to the gastrointestinal tract. LWT_Food Sci. Technol. 2020, 118, 108756. [CrossRef]

26. Dimitrellou, D.; Kandylis, P.; Kokkinomagoulos, E.; Hatzikamari, M.; Bekatorou, A. Emmer-Based Beverage Fortified with Fruit Juices. Appl. Sci. 2021, 11, 3116. [CrossRef]

27. Muncey, L.; Hekmat, S. Development of Probiotic Almond Beverage Using Lacticaseibacillus rhamnosus GR-1 Fortified with Short-Chain and Long-Chain Inulin Fibre. Fermentation 2021, 7, 90. [CrossRef]

28. Dias, C.O.; dos Santos Opuski de Almeida, J.; Pinto, S.S.; de Oliveira Santana, F.C.; Verruck, S.; Müller, C.M.O.; Prudêncio, E.S.; de Mello Castanho Amboni, R.D. Development and physico-chemical characterization of microencapsulated bifidobacteria in passion fruit juice: A functional non-dairy product for probiotic delivery. Food Biosci. 2018, 24, 26-36. [CrossRef]

29. Dos Santos Filho, A.L.; Freitas, H.V.; Rodrigues, S.; Abreu, V.K.G.; de Oliveira Lemos, T.; Gomes, W.F.; Naraind, N.; Pereiraaet, A.L.F. Production and stability of probiotic cocoa juice with sucralose as sugar substitute during refrigerated storage. LWT-Food Sci. Technol. 2019, 99, 371-378. [CrossRef]

30. Da Costa, G.M.; de Carvalho Silva, J.V.; Mingotti, J.D.; Barão, C.E.; Klososki, S.J.; Pimentel, T.C. Effect of ascorbic acid or oligofructose supplementation on $L$. paracasei viability, physicochemical characteristics and acceptance of probiotic orange juice. LWT_Food. Sci. Technol. 2017, 75, 195-201. [CrossRef]

31. Faridy, J.C.M.; Stephanie, C.G.M.; Gabriela, M.M.O.; Cristian, J.M. Biological Activities of Chickpea in Human Health (Cicer arietinum L.). A Review. Plant Foods Hum. Nutr. 2020, 75, 142-153. [CrossRef]

32. Nikmaram, N.; Roohinejad, S.; Koubaa, M.; Barba, F.J.; Greiner, R.; Johnson, S.K. Recent advances in $\gamma$-aminobutyric acid (GABA) properties in pulses: An overview. J. Organ. Behav. 2007, 28, 303-325.

33. Newman, C.W.; Roth, N.J.; Newman, R.K.; Lockerman, R.H. Protein quality of chickpea (Cicer arietinum L.). Nutr. Rep. Int. 1987, $36,1-5$.

34. Wang, S.; Chelikani, V.; Serventi, L. Evaluation of chickpea as alternative to soy in plant-based beverages, fresh and fermented. LWT-Food Sci. Technol. 2018, 97, 570-572. [CrossRef]

35. Mesquita, M.C.; dos Santos Leandro, E.; de Alencar, E.R.; Botelho, R.B.A. Fermentation of chickpea (Cicer arietinum L.) and coconut (Coccus nucifera L.) beverages by Lactobacillus paracasei subsp. paracasei LBC 81: The influence of sugar content on growth and stability during storage. LWT-Food Sci. Technol. 2020, 132. [CrossRef]

36. Rincon, L.; Botelho, R.B.A.; de Alencar, E.R. Development of novel plant-based milk based on chickpea and coconut. LWT-Food Sci. Technol. 2020, 128, 109479. [CrossRef]

37. Bautista-Gallego, J.; Arroyo-López, F.N.; Rantsiou, K.; Jiménez-Díaz, R.; Garrido-Fernández, A.; Cocolin, L. Screening of lactic acid bacteria isolated from fermented table olives with probiotic potential. Food Res. Int. 2013, 50, 135-142. [CrossRef]

38. Van de Guchte, M.; Serror, P.; Chervaux, C.; Smokvina, T.; Ehrlich, S.D.; Maguin, E. Stress responses in lactic acid bacteria. Antonie van Leeuwenhoek. 2002, 82, 187-216. [CrossRef]

39. De Angelis, M.; Gobbetti, M. Environmental stress responses in Lactobacillus: A review. Proteomics 2004, 4, 106-122. [CrossRef] [PubMed]

40. Fiocco, D.; Longo, A.; Arena, M.P.; Russo, P.; Spano, G.; Capozzi, V. How probiotics face food stress: They get by with a little help. Crit. Rev. Food Sci. Nutr. 2020, 60, 1552-1580. [CrossRef]

41. Jukanti, A.K.; Gaur, P.M.; Gowda, C.L.L.; Chibbar, R.N. Nutritional quality and health benefits of chickpea (Cicer arietinum L.): A review. Br. J. Nutr. 2012, 108, S11-S26. [CrossRef] [PubMed]

42. Cortés-Giraldo, I.; Megías, C.; Alaiz, M.; Girón-Calle, J.; Vioque, J. Purification of free arginine from chickpea (Cicer arietinum) seeds. Food Chem. 2016, 192, 114-118. [CrossRef] [PubMed] 
43. Elizaquível, P.; Sánchez, G.; Salvador, A.; Fiszman, S.; Dueñas, M.T.; López, P.; de Palencia, P.F. Evaluation of yogurt and various beverages as carriers of lactic acid bacteria producing 2-branched (1,3)- $\beta$-d-glucan. J. Dairy Sci. 2011, 94, 3271-3278. [CrossRef] [PubMed]

44. Casarotti, S.N.; Penna, A.L.B. Acidification profile, probiotic in vitro gastrointestinal tolerance and viability in fermented milk with fruit flours. Int. Dairy J. 2015, 41, 1-6. [CrossRef]

45. Kocer, E.; Unal, G. Effects of different prebiotics on viability under in vitro gastrointestinal conditions and sensory properties of fermented milk. Ital. J. Food Sci. 2018, 30, 568-582.

46. Boke, H.; Aslim, B.; Alp, G. The role of resistance to bile salts and acid tolerance of exopolysaccharides (EPSs) produced by yogurt starter bacteria. Arch. Biol. Sci. 2010, 62, 323-328. [CrossRef]

47. Uriot, O.; Denis, S.; Junjua, M.; Roussel, Y.; Dary-Mourot, A.; Blanquet-Diot, S. Streptococcus thermophilus: From yogurt starter to a new promising probiotic candidate? J. Funct. Foods 2017, 37, 74-89. [CrossRef]

48. Costa, M.G.M.; Ooki, G.N.; Vieira, A.D.S.; Bedani, R.; Saad, S.M.I. Synbiotic Amazonian palm berry (açai, Euterpe oleracea Mart.) ice cream improved Lactobacillus rhamnosus GG survival to simulated gastrointestinal stress. Food Funct. 2017, 8, 731-740. [CrossRef] [PubMed]

49. Bedani, R.; Rossi, E.A.; Saad, S.M.I. Impact of inulin and okara on Lactobacillus acidophilus La-5 and Bifidobacterium animalis Bb-12 viability in a fermented soy product and probiotic survival under in vitro simulated gastrointestinal conditions. Food Microbiol. 2013, 34, 382-389. [CrossRef]

50. Wang, J.; Guo, Z.; Zhang, Q.; Yan, L.; Chen, W.; Liu, X.-M.; Zhang, H.-P. Fermentation characteristics and transit tolerance of probiotic Lactobacillus casei Zhang in soymilk and bovine milk during storage. J. Dairy Sci. 2009, 92, 2468-2476. [CrossRef] [PubMed]

51. Begley, M.; Gahan, C.G.M.; Hill, C. The interaction between bacteria and bile. FEMS Microbiol. Rev. 2005, 29, 625-651. [CrossRef]

52. Picard, C.; Fioramonti, J.; Francois, A.; Robinson, T.; Neant, F.; Matuchansky, C. Review article: Bifidobacteria as probiotic agents-Physiological effects and clinical benefits. Aliment. Pharmacol. Ther. 2005, 22, 495-512. [CrossRef] [PubMed]

53. Bedani, R.; Vieira, A.D.S.; Rossi, E.A.; Saad, S.M.I. Tropical fruit pulps decreased probiotic survival to invitro gastrointestinal stress in synbiotic soy yoghurt with okara during storage. LWT-Food Sci. Technol. 2014, 55, 436-443. [CrossRef]

54. Champagne, C.P.; Gardner, N.J. Effect of storage in a fruit drink on subsequent survival of probiotic lactobacilli to gastro-intestinal stresses. Food Res. Int. 2008, 41, 539-543. [CrossRef] 